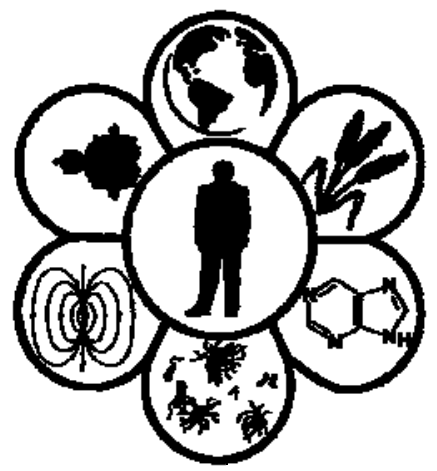

Вісник Дніпропетровського університету. Біологія, медицина Vìsnik Dnìpropetrovs'kogo unìversitetu. Seriâ Bìologiâ, medicina

Visnyk of Dnipropetrovsk University. Biology, medicine

Vìsn. Dnìpropetr. Unìv. Ser. Bìol. Med. 2014. 5(1), 58-61.

doi: $10.15421 / 021412$

ISSN 2310-4155 print

ISSN 2312-7295 online

www.medicine.dp.ua

УДК 616.1+612

\title{
Аутоімунна реакція проти нейроспецифічних білків та якість життя паціснтів з уродженою вадою серця
}

\author{
О.М. Лисунець ${ }^{1}$, В.С. Недзвецький ${ }^{2}$ \\ ${ }^{\prime}$ УкрдержНДІ медико-соиіальних проблем інвалідності МОЗ України, Дніпропетровськ, Україна \\ ${ }^{2}$ Дніпропетровський національний університет імені Олеся Гончара, Дніпропетровськ, Україна
}

Представлено результати експериментальних досліджень аутоімунної реакції, спрямованої проти нейроспецифічних білкових антигенів у пацієнтів з уродженою вадою серця. Титр аутоантитіл до білків мозку у таких пацієнтів значено перевищує показники контрольної групи. Підвищення титру аутоантитіл корелює зі здатністю до вирішення задач на виявлення складних аналогій $\mathrm{i}$ зниженням якості життя. Таким чином, зниження якості життя та розвиток пізнавального дефіциту у пацієнтів із патологіями серцево-судинної системи може бути асоційоване з аутоімунною реакцією проти специфічних білків клітин нервової тканини. Отримані результати показують, що генерація аутоантитіл у пацієнтів з уродженим пороком серця асоційована 3 розвитком когнітивного дефіциту. Однією 3 найважливіших причин пізнавального спаду може бути стан гіпоксії під час проведення хірургічного втручання. Наслідки гіпоксії, у свою чергу, супроводжуються хронічним оксидативним стресом. Молекулярні та клітинні порушення вільними радикалами - поширена причина широкого спектру патологій. Подальші дослідження необхідні для валідизації діагностичних критеріїв відносно диференціації причин розвитку пізнавального дефіциту у групі пацієнтів 3 уродженим пороком серця. Такі дослідження дозволять розкрити механізми впливу гіпоксичних пошкоджень у результаті розвитку оксидативного стресу у клітинах нервової тканини. Розуміння зв'язку між спадом пізнавальної функції та патологією серцево-судинної системи необхідно для точного клінічного діагнозу та раннього попередження ускладнень.

Ключові слова: аутоантитіла; якість життя; пізнавальний дефіцит; нейроспецифічні антигени

\section{Autoimmune reaction against neurospecific proteins and life quality of patients with congenital heart failure}

\author{
H.M. Lisunets, V.S. Nedzvetsky
}

\section{Oles Honchar Dnipropetrovsk National University, Dnipropetrovsk, Ukraine}

The results of experimental investigation of autoimmune reaction targeted against neirospecific protein antigens in patients with congenital heart failure are presented. It is shown that titer for autoanibodies to these patients' brain proteins is significantly higher compared with healthy persons. Elevation of titer of these autoantibodies is correlated with the ability to solve tasks for revealing complex analogies and decrease of life quality. Therefore, worsening of life quality and development of cognitive deficit in patients with cardiovascular diseases might be associated with autoimmune reaction against specific proteins of nervous tissue cells. The results obtained demonstrate that generation of autoantibodies in patients with congenital heart failure is linked with the cognitive deficit. One of the most important causes of cognitive decline could be hypoxia state due to surgery intervention. Consequences of hypoxia, in their turn, are accompanied by chronic oxidative stress. Molecular and cell injuries induced by free radicals are known to be the widely spread cause of various pathologies. Further investigations for validation of diagnostic hallmarks for estimation of the origin of progression of the cognitive deficit in patients with congenital heart failure are needed. These studies will allow clarifying mechanisms of influence of hypoxia-induced injuries associated with the aggravation of oxidative stress in nervous tissue cells. Understanding of relationship between decline of cognitive function and pathologies of cardiovascular system is necessary for more precise clinical diagnostics of the early prevention of possible complications and proper treatment of patients.

Keywords: autoantibodies; life quality; cognitive deficit; neurospecific antigens

Дніпропетровський національний університет імені Олеся Гончара, пр. Гагаріна, 72, Дніпропетровськ, 49010, Україна. Oles Honchar Dnipropetrovsk National University, Gagarin Ave., 72, Dnipropetrovsk, 49010, Ukraine. Tel.: +38-097-774-61-57.Fax:+38-052-713-50-02.E-mail: lysunets.olena@gmail.com,nedzvetskyvictor@ukr.net 


\section{Вступ}

Прогресивне зростання кількості захворювань серцево-судинної системи та широке коло ускладнень, асоційованих із погіршенням функцій ЦНС, зумовлюють особливий інтерес до вивчення молекулярних i клітинних механізмів, які викликають порушення пам'яті, здатності до навчання та розвиток пізнавального дефіциту в людей із різними серцевими патологіями. Останніми роками інтенсивно досліджуються причини та патогенез розвитку пізнавального дефіциту у пацієнтів із серцевою недостатністю та вродженою вадою серця (ВВС) (Pressler et al., 2010).

Серцево-судинна патологія може бути одним із причинних факторів погіршення показників психомоторної реакції, пам'яті та виконавчих функцій принаймні в одного із п'яти пацієнтів. Істотним ускладненням у вивченні зв'язку серцевої патології з нервовими розладами $\epsilon$ необхідність диференціації біохімічних, фізіологічних і соціальних факторів (Sloan et al., 2009). Актуальність досліджень підкреслюється також сучасними вимогами визначення показників якості життя в контексті спаду нервових функцій у таких пацієнтів (Pressler et al., 2010). Молекулярні механізми, які спричинюють функціональні розлади ЦНС у пацієнтів із серцево-судинними патологіями, залишаються не вивченими. Ішемічні ушкодження у тканині мозку внаслідок хронічної недостатності кисню індукують порушення окисно-відновного балансу та розвиток окисного стресу. Окисний стрес, у свою чергу, є одним iз найпоширеніших факторів, що індукують структурні та функціональні порушення у клітинах нервової системи (Pratico and Delanty, 2000). Клітини нервової системи $\epsilon$ одними 3 найчутливіших до окисних ушкоджень порівняно з клітинами інших тканин. Нейродегенерація, що викликається окисним стресом, може бути однією 3 важливих причин порушень функцій ЦНС, зокрема, пізнавальної здатності, навчання та пам'яті (Baydas et al., 2005). У хворих із ВВС виявляється підвищений рівень факторів запальної реакції, а також ознаки гіпоксії та окисного стресу, порушення проникності ГЕБ у ранньому післяопераційному періоді (Wolman et al., 1999; Mariani et al., 2005).

Незважаючи на значний прогрес медико-біологічних наук в останні десятиліття, залишаються не з'ясованими причини порушення показників вищої нервової діяльності у хворих на ВВС. Не розкрита також роль імунних реакцій, зокрема, генерації аутоантитіл до нейроспецифічних білків у системних порушеннях взаємодії імунної та нервової систем. Мета роботи визначити аутоантитіла, їх титр i специфічність до антигенів тканини мозку у пацієнтів із ВВС.

\section{Матеріал і методи досліджень}

Кров відбирали у пацієнтів із ВВС на другу добу після надходження до стаціонару. У зразках сироватки методом імуноблотингу визначали присутність аутоантитіл. Специфічність тестували до антигенів із відмінними фізико-хімічними властивостями: розчинної, мембранної та цитоскелетної фракцій білків. Відповідні фракції, збагачені білками клітин мозку, одержували як описано раніше (Nedzvetsky et al., 2006; Baydas et al., 2003). Зразки білків мозку розділяли електрофорезом у поліакриламідному гелі (Baydas et al., 2003). Імуноблотинг iз моноспецифічними антитілами проти гліального фібрилярного кислого білка (ГФКБ) проводили як це описано раніше (Nedzvetsky et al., 2006).

Отримані результати сканували та аналізували за допомогою комп'ютерної програми AlfaImager 2000. Для кожної сироватки пацієнтів із $\mathrm{BBC}$ визначали максимальне розведення, за якого інтенсивність забарвлення основних поліпептидних зон була не меншою за умовну одиницю. Всі проби білків мозку містили однакову кількість загального білка (30 мкг). Вміст загального білка у пробах визначали методом Лоурі в модифікації Міллера (Miller, 1959). У роботі застосовували для дослідження когнітивної функції прогресивні матриці Равена, для дослідження якості життя хворого методику оцінки якості життя Всесвітньої організації охорони здоров'я (українську версію).

Отримані дані обробляли з використанням стандартних методів математичної статистики (пакет програм Statistica 6.0).

\section{Результати та їх обговорення}

Результати дослідження показали присутність у сироватці крові пацієнтів із ВВС аутоантитіл, які специфічно реагували 3 білками всіх досліджених фракцій. Найінтенсивніша реакція (за розведеня сироваток 1:200) виявлена із фракціями цитоскелетних і мембранних білків мозку. Менш виражена реакція аутоантитіл виявлена також із розчинними білками, виділеними буфером із низькою іонною силою.

Реакцію аутоантитіл до антигенів нервової тканини виявлено у 47 з 52 пацієнтів із групи $\mathrm{BBC}$ і в 3 із 38 зразків сироватки контрольної групи. Імуноблотингом ідентифіковано молекулярну масу білкових антигенів нервової тканини, з якими специфічно реагували аутоантитіла пацієнтів із ВВС. Більшість поліпептидів, які специфічно розпізнавалися аутоантитілами, мала молекулярну масу в діапазоні 30-90 кДа. Враховуючи фізико-хімічні властивості білків кожної фракції та молекулярну масу даних поліпептидів, можна припустити, що саме нерозчинні цитоскелетні білки та білки, асоційовані з мембранами, можуть бути основною мішенню специфічно спрямованої аутоімунної реакції пацієнтів із ВВС. Умови проведення імуноблотингу дозволяють виключити неспецифічні реакції.

Аутоантитіла, які реагували 3 нервовоспецифічними антигенами молекулярною масою понад 90 кДа, були виявлені у $37 \%$ пацієнтів із ВВС. У переважній більшості когорти пацієнтів, у яких виявлено аутоімунну реакцію, більшість аутоантитіл (94\%) були специфічними до білків масою 37-50 кДа. На особливу увагу заслуговує факт, що такі антигени були представлені в усіх трьох досліджених фракціях.

Імуноблотинг білкових фракцій печінки показав, що антитіла із сироваток пацієнтів не мали специфічної спрямованості проти антигенів печінки людини та щура. 
Зважаючи на те, що у печінці найширше представлені білкові антигени хребетних, цей факт підтверджує спрямованість аутоімунної реакції переважно проти нервовоспецифічних антигенів.

Існують різні гіпотези про природу та роль аутоантитіл. Однак не викликає сумнівів факт їх присутності в організмі людини та інших хребетних. Природні аутоантитіла являють собою пул молекул, які $\epsilon$ частиною репертуару нормальних імуноглобулінів (Wright et al., 2009). Незважаючи на значний прогрес молекулярних методів дослідження аутоімунних реакцій, механізми активації лімфоцитів і синтезу аутоантитіл проти ЦНС-антигенів залишаються не повністю зрозумілими (Zhang and Popovich, 2011).

На сьогодні $є$ неоднозначні дані про присутність аутоантитіл до антигенів ЦНС за різних патологій нервової системи. Аутоімунна реакція може бути індукована органічними ушкодженнями нервової тканини, порушенням проникності ГЕБ, порушеннями механізмів саморозпізнавання в імунній системі, а також збігом усіх цих причинних факторів (Levin et al., 2010). Однією 3 найприйнятніших i ймовірних причин генерації аутоантитіл до антигенів нервової тканини вважається порушення цілісності ГЕБ і доступність антигенів нервової тканини для імунокомпетентних клітин (Arshavsky, 2006).

Останнім часом показано, що переважна кількість різних за природою ушкоджувальних факторів викликає активацію, у першу чергу, гліальних клітин - астроцитів та мікроглії (Wright et al., 2009). У ЦНС саме астроцити за рахунок щільних контактів із судинами формують ГЕБ. Можливість ушкоджень ГЕБ унаслідок гіпоксії доведено численними клінічними та експериментальними дослідженнями. На ранніх стадіях хронічної ішемії мозку мають місце порушення у вигляді підвищення вмісту нейротропних аутоантитіл. Уже на початкових стадіях хронічної ішемії при відносно мінімальних клінічних та інструментальних симптомах може бути стимульована генералізована імунізація до структурних компонентів нервової тканини (Zhang and Popovich, 2011). Ішемія активує процеси як некротичної, так i апоптичної загибелі клітин мозку, що стимулює утворення цитокінів і нейротрофічних факторів гліальними клітинами. 3 одного боку, активація глії за умов ушкоджень забезпечує нормальну життєдіяльність нейронів, а з іншого - сприяє синтезу та вивільненню факторів, які активують імунні реакції (Levin et al., 2010).

У багатьох експериментальних моделях показано, що розвиток окисного стресу $є$ наслідком порушення балансу між активністю мітохондрій і метаболізмом субстратів циклу Кребса - донорів протонів для дихального ланцюга. Одним із найпоширеніших факторів, здатним індукувати астрогліоз, є саме окисний стрес (Arshavsky, 2006). Мультифакторна спрямованість наслідків окисних ушкоджень зумовлює надзвичайну складність розкриття молекулярних i клітинних механізмів, які визначають погіршення пам'яті та розвиток пізнавального дефіциту. У відповідь на окисні ушкодження в нервовій тканині активується синтез медіаторів запальної реакції, які одночасно є стимуляторами імунної відповіді (Kuboyama et al., 2010). ГЕБ забезпечує відособленість клітин нервової тканини від контакту 3 імунною системою. Астроцити формують ГЕБ завдяки щільним безпосереднім контактам астроцитів з ендотеліальними клітинами судин мозку. Крім формування ГЕБ астроцити виконують у мозку велику кількість життєво важливих функцій. Вони забезпечують енергетичні витрати нейронів, іонний баланс, синтезують широкий спектр цитокінів і несуть на своїй поверхні рецептори, подібні до рецепторів лімфоцитів і макрофагів (Sofroniew and Vinters, 2010). У пацієнтів із гострим ішемічним інсультом визначаються аутоантитіла, спрямовані проти антигенів клітин ЦНС (Ankeny and Popovich, 2010). Автори припускають, що провідну роль у генерації таких антимозкових антитіл відіграють ушкодження ГЕБ $\mathrm{i}$ контакт нервовоспецифічних антигенів 3 імунокомпетентними клітинами.

3 огляду на той факт, що у пацієнтів із ВBC оперативне втручання супроводжувалось гіпоксією, можна припустити високу імовірність розвитку окисного стресу. У свою чергу, розвиток окисного стресу у тканині мозку певною мірою може спричиняти характерну захисну реакцію гліальних клітин - гліоз. Астроцити роблять найбільший внесок у таку реактивну відповідь. У ході астрогліозу астроцити активують синтез і вивільнення різних ростових факторів, сигнальних молекул, у тому числі фактор некрозу пухлин та інтерлейкіни, які беруть безпосередню участь в активації як імунних реакцій, так і запального процесу. Враховуючи це, можна припустити, що саме астроцити є сполучною ланкою між імунною та нейроендокринною системою у ході таких подій. На користь цього свідчать також результати досліджень аутоантитіл проти цитоскелетного маркера астроцитів (ГФКБ), які виявлені майже у 30\% пацієнтів iз запальними захворюваннями ЦНС і множинним склерозом (Bien, 2011). Дефекти ГЕБ сприяють контактуванню антигенів ЦНС з імунокомпетентними клітинами. Внаслідок такої стимуляції може розвиватися аутоімунна реакція до нейроспецифічних антигенів.

Діагностика та розуміння імунно-опосредкованих патологій отримали значний прогрес завдяки ідентифікації аутоантител у сироватці та ЦСЖ пацієнтів із різними захворюваннями. Недавно виявлені аутоантитіла, які реагують із поверхневими антигенами нейронів, зокрема - рецепторами, каналами та асоційованими 3 ними білками. Небезпідставно припускають можливий прямий патогенетичний ефект аутоантитіл на нейрони ЦНС. Існують приклади досить повно вивчених синдромів типово асоційованих $з$ аутоантитілами до антигенів мозку (Bien, 2011).

Кардоіваскулярні фактори ризику можуть ініціювати порушення ГЕБ. Оскільки мозок $є$ захищеним ГЕБ від реакцій імунної системи, навіть незначне ослаблення бар'єрної функції може викликати дисбаланс взаємин нейроендокринної та імунної систем. Зокрема, для процесу консолідації пам'яті необхідний синтез нових макромолекул, які відрізняються лише конформаційними детермінантами. Однак імунна система здатна розпізнавати такі макромолекули як «не свої» антигени. Варто врахувати, що поки така концепція залишається гіпотетичною та має потребу в експериментальних аргументах (Arshavsky, 2006). На підставі проведеного клінічного дослідження, аналізу психологічних особли- 
востей та якості життя доцільно звернути увагу на патофізіологічні аспекти нервово-психічних розладів у даної групи пацієнтів. Якісний аналіз когнітивної сфери пацієнта проводили за допомогою методики «Прогресивні матриці Равенна» (табл.).

Таблиия

Аналіз порушень когнітивної сфери за допомогою методики «Прогресивні матриці Равена»

\begin{tabular}{|l|c|}
\hline Рівень когнітивних функцій & Частка порушень, \% \\
\hline Високий & 4,8 \\
\hline Середній & 69,8 \\
\hline Нижче середнього & 25,4 \\
\hline
\end{tabular}

Під час дослідження рівня наочних форм мислення за допомогою прогресивних матриць Равена виявлено, що основна маса результатів припадала на середній рівень наочних форм мислення, дуже низький рівень наочного інтелекту не був діагностований. Також під час якісного аналізу помилок, що допускаються випробуваними, нами виявлено статистично значимі ознаки. Хворі з оперованими ВВС найчастіше допускають помилки у складних кластерах завдань (систематизація мислення, відновлення складних логічних зв'язків, розкриття істотних зв'язків між предметами та явищами). Слід зазначити, що за показником складних аналогій виявлені взаємозв'язки 3 усіма напрямами обмеження життєдіяльності (навчання та застосуванню знань, спілкування, мобільність, побутове життя, міжособова взаємодія).

Таким чином, для дослідженої групи пацієнтів 3 оперованими ВBC притаманне не тільки зниження інтелектуальних показників, а і якісне порушення наочних форм мислення. Такі інтелектуальні показники у сполученні 3 неврологічними порушеннями можуть служити додатковим діагностичним критерієм рівня непрацездатності.

\section{Висновки}

У пацієнтів із ВВС генерація аутоантитіл, спрямованих в основному проти нейроспецифічних білків, асоційована 3 когнітивним спадом. Однією з причин розвитку аутоімунної реакції та пізнавального дефіциту в дослідженій групі може бути гіпоксія під час хірургічного втручання. Подальші дослідження також необхідні для валідизації діагностичних критеріїв щодо диференціації причин розвитку пізнавального дефіциту у групах пацієнтів із ВВС. Подібні дослідження дозволять розкрити та з'ясувати вплив гіпоксичних ушкоджень у результаті розвитку оксидативного стресу у клітинах нервової тканини. Виявлення зв'язку між погіршенням пізнавальної функції та серцево-судинними патологіями може бути використане для точнішого клінічного діагнозу, раннього попередження та ставлення до пацієнта.

\section{Бібліографічні посилання}

Ankeny, D.P., Popovich, P.G., 2010. B cells and autoantibodies: Complex roles in CNS injury. Trends Immunol. 319(9), 332-338.
Arshavsky, Y.I., 2006. Alzheimer's disease, brain immune privilege and memory: A hypothesis. J. Neural Transmition. 113(11), 1697-1707.

Baydas, G., Koz, S.T., Tuzcu, M., Etem, E., Nedzvetsky, V.S., 2007. Melatonin inhibits oxidative stress and apoptosis in fetal brains of hyperhomocysteinemic rat dams. J. Pineal Res. 43, 225-231.

Baydas, G., Nedzvetskii, V.S., Nerush, P.A., Kirichenko, S.V., Yoldas, T., 2003. Altered expression of NCAM in hippocampus and cortex may underlie memory and learning deficits in rats with streptozotocin-induced diabetes mellitus. Life Sci. 73(15), 1907-1916.

Bien, C.G., 2011. Antibody-associated diseases of the gray matter of the CNS: Diagnosis and treatment. Nervenarzt. 82(8), 986-993.

Kuboyama, K., Harada, H., Tozaki-Saitoh, H., Tsuda, M., Ushijima, K., Inoue, K., 2011. Astrocytic P2Y1 receptor is involved in the regulation of cytokine/chemokine transcription and cerebral damage in a rat model of cerebral ischemia. J. Cereb. Blood Flow Metab. 31, 1930-1941.

Laemmli, O.H., 1970. Cleavage of structural proteins during the assembly of the head of bacteriophage T4. Nature 227(1), 243-246.

Levin, E.C., Acharya, N.K., Han, M., Zavareh, S.B., Sedeyn, J.C., Venkataraman, V., Nagele, R.G., 2010. Brain-reactive autoantibodies are nearly ubiquitous in human sera and may be linked to pathology in the context of blood-brain barrier breakdown. Brain Res. 1345(3), 221-232.

Mariani, E., Polidori, M.C., Cherubini, A., Mecocci, P., 2005. Oxidative stress in brain aging, neurodegenerative and vascular diseases: An overview. J. Chromatogr. B Analyt. Technol. Biomed. Life Sci. 827, 65-75.

Miller, G.L., 1959. Protein determination for large numbers of samples. Anal. Chem. 31(5), 964-966.

Nedzvetsky, V.S., Tuzcu, M., Yasar, A., Tikhomirov, A.A., Baydas, G., 2006. Effects of vitamin E against aluminum neurotoxicity in rats. Biochem. (Mosc). 71(3), 239-244.

Pratico, D., Delanty, N., 2000. Oxidative injury in diseases of the central nervous system: Focus on Alzheimer's disease. Am. J. Med. 109, 577-585.

Pressler, S.J., Subramanian, U., Kareken, D., Perkins, S.M., Gradus-Pizlo, I., Sauvé, M.J., Ding, Y., Kim, J., Sloan, R., Jaynes, H., Shaw, R.M., 2010. Cognitive deficits in chronic heart failure. Nursery Research 59(2), 127-139.

Pressler, S.J., Subramanian, U., Kareken, D., Perkins, S.M., Gradus-Pizlo, I., Sauvé, M.J., Ding, Y., Kim, J., Sloan, R., Jaynes, H., Shaw, R.M., 2010. Cognitive deficits and healthrelated quality of life in chronic heart failure. J. Cardiovasc. Nurs. 25(3), 189-198.

Sloan, R.S., Pressler, S.J., 2009. Cognitive deficits in heart failure: Re-cognition of vulnerability as a strange new world. J. Cardiovasc. Nurs. 24(3), 241-248.

Sofroniew, M.V., Vinters, H.V., 2010. Astrocytes: Biology and pathology. Acta Neuropathol. 119, 7-35.

Wolman, N.A., Nussmeier, A., Aggarwal, R.L., 1999. Cerebral injury after cardiac surgery; identification of a group at extraordinary risk. Stroke 30, 514-522.

Wright, B.R., Warrington, A.E., Edberg, D.D., Rodriguez, M., 2009. Cellular mechanisms of central nervous system repair by natural autoreactive monoclonal antibodies. Arch. Neurol. 66(12), 1456-1459.

Zhang, Y., Popovich, P., 2011. Roles of autoantibodies in central nervous system injury. Discov. Med. 11(60), 395-402.

Надійшла до редколегії 27.03.2014 